\title{
植物的臭氧污染胁迫效应研究进展
}

\author{
许 宏 $^{1}$ 杨景成 ${ }^{2}$ 陈圣宾 ${ }^{1}$ 蒋高明 $^{1}$ 李永庚 $^{1 *}$ \\ （1 中国科学院植物研究所植被和环境变化国家重点实验室 北京 100093）（2 北京自然博物馆 北京 100050)
}

\begin{abstract}
摘 要 近地面空气中的臭氧 $\left(\mathrm{O}_{3}\right)$ 属于二次污染物, 是由氮氧化物 $\left(\mathrm{NO}_{\mathrm{x}}\right)$ 和挥发性有机物 $(V O C s)$ 等前体物在一定 的环境条件下形成的。近年来, 全球受 $\mathrm{O}_{3}$ 污染的区域增加, 污染程度也日趋严重。 $\mathrm{O}_{3}$ 污染对植物的危害引起了国 内外研究人员的广泛关注。众多研究发现, 不同植物对 $\mathrm{O}_{3}$ 的敏感性不同, 其大小主要取决于植物自身的特性及环 境因素; $\mathrm{O}_{3}$ 污染降低植物的净同化作用, 减缓植物生长, 改变同化物的分配, 可对物种间的相互关系以及生态系统 结构产生深远影响。该文在综述了国内外研究进展的基础上,提出我国在 $\mathrm{O}_{3}$ 污染研究领域应深入研究以下几个 方面 :1)选育具有对 $\mathrm{O}_{3}$ 污染抗性较强的植物尤其是作物品种 ,2) 深入研究减轻 $\mathrm{O}_{3}$ 污染对植物危害的栽培管理措 施 3) 加强研究 $\mathrm{O}_{3}$ 污染对我国自然生态系统的影响 ;4)研究植被在治理 $\mathrm{O}_{3}$ 污染中的积极作用。
\end{abstract}

关键词 臭氧 同化作用 同化物分配 全球变化 污染

\section{REVIEW OF PLANT RESPONSES TO OZONE POLLUTION}

\author{
XU Hong ${ }^{1}$, YANG Jing-Cheng ${ }^{2}$, CHEN Sheng-Bin ${ }^{1}$, JIANG Gao-Ming ${ }^{1}$, and LI Yong-Geng ${ }^{1}$ * \\ ${ }^{1}$ Key Laboratory of Vegetation and Environmental Change , Institute of Botany , Chinese Academy of Sciences , Beijing 100093 , China , and ${ }^{2}$ Beijing \\ Natural Museum , Beijing 100050 , China
}

\begin{abstract}
Ozone $\left(\mathrm{O}_{3}\right)$ is highly beneficial in many ways, such as filtering ultraviolet radiation in the upper atmosphere, but $\mathrm{O}_{3}$ at ground level is a serious pollutant. High $\mathrm{O}_{3}$ concentration causes the damage to plants ranging from minimal visible symptoms to substantial inhibition of productivity , and species- or cultivar-specific responses exist. Interactions between plants and herbivorous insect pests or plant pathogens may be affected by $\mathrm{O}_{3}$. Decreased carbon flow above- and below-ground in high $\mathrm{O}_{3}$ environment could significantly decrease biodiversity. Therefore, $\mathrm{O}_{3}$ will affect terrestrial ecosystems substantially. The following aspects are suggested to be further studied in China $: 1$ ) the comparison and selection of plant species or cultivars with high $\mathrm{O}_{3}$ resistance , 2) the possible methods which can alleviate $\mathrm{O}_{3}$ damage to plants , 3) $\mathrm{O}_{3}$ effects on the natural ecosystems in China , and 4) the positive function of vegetation in decreasing $\mathrm{O}_{3}$ pollution.
\end{abstract}

Key words ozone, assimilation , photosynthate allocation, global change , pollution

臭氧 $\left(\mathrm{O}_{3}\right)$ 在吸收紫外线、杀菌与消毒等方面发 挥着重要作用。然而，低空中的 $\mathrm{O}_{3}$ 对生物体及生态 系统健康是有害的。

$\mathrm{O}_{3}$ 属于二次污染物, 它是由机动车、工厂等人 为源以及天然源排放的氮氧化物 $\left(\mathrm{NO}_{\mathrm{x}}\right)$ 和挥发性有 机物 (VOCs) 等一次污染物在大气中经过光化学反 应形成的 (Ryerson et al .,2001)。其主要反应可表 示为 $: \mathrm{VOCs}+\mathrm{NO}_{\mathrm{x}}+\mathrm{h} \nu \rightarrow \mathrm{O}_{3}+$ 其它氧化剂。位于 $60^{\circ}$ $\mathrm{N} \sim 60^{\circ} \mathrm{S}$ 之间的一些大城市, 在湿度低并且气温在 $24 \sim 32{ }^{\circ} \mathrm{C}$ 的晴天中午或午后都可能发生光化学烟 雾, 可导致数百公里外的植物生长受阻甚至死亡。 其中, $\mathrm{O}_{3}$ 被认为是光化学烟雾最主要的产物, 占总 氧化剂的 $90 \%$ 以上。我国中东部地区的 $\mathrm{O}_{3}$ 污染问
题十分突出。例如 北京市早在 1986 年夏季就出现 了光化学烟雾生成的迹象，且近 10 年来日趋严重 ( Tang et al . , 1995 ; Zhang et al . , 1997 ; 王淑兰和柴 发合，2002）; 1998 年 8 月，北京空气中 $\mathrm{O}_{3}$ 浓度最大 值和平均值分别为 431.2 和 $122.1 \mu \mathrm{g} \mathrm{m} \mathrm{m}^{-3}$ (张远航 等, 1998) 分别相当于 215 和 $61 \mu \mathrm{g} \mathrm{kg}{ }^{-1}$;常熟市农 田中的最高 $\mathrm{O}_{3}$ 浓度也达到了 $160 \mu \mathrm{g} \mathrm{kg}$ k $^{-1}$ (刘建栋 等 ,2003) ，远远超过 $40 \mu \mathrm{g} \mathrm{kg}{ }^{-1}$ 的临界浓度。

近 50 年来, 近地面空气中 $\mathrm{O}_{3}$ 浓度升高对农田、 森林以及人类的健康都产生了极大色害。例如,20 世纪 80 年代末至 90 年代初美国的 $N P P$ 每年因 $\mathrm{O}_{3}$ 污染而减少 $2.6 \% \sim 6.8 \%$, C 沉降自 1950 年以来减 少了 $18 \sim 38 \mathrm{Tg} \mathrm{G} \mathrm{a} \mathrm{a}^{-1}$ (Felzer et al. , 2004), 每年因 
$\mathrm{O}_{3}$ 污染造成的农业损失达 30 亿美元 (Adams et al. , $1985)$ 欧洲的 $\mathrm{O}_{3}$ 烟雾每年对农作物造成高达 60 亿 欧元的损失 (Pearce，2002) ;我国长江三角洲地区因 $\mathrm{O}_{3}$ 浓度过高造成的农业损失为 14.75 亿元人民币 (Feng et al. ,2003)。

深入了解不同植物种 (品种) 对 $\mathrm{O}_{3}$ 的反应及其 反应机理, 有利于指导育种专家篮选出抗性较强的 作物品种以应对全球变化带来的负效应; 研究不同 环境下植物对 $\mathrm{O}_{3}$ 浓度增高的响应, 有利于指导农业 生产以及生态系统管理, 同时还有利于正确估计由 $\mathrm{O}_{3}$ 污染而带来的农业损失。为此现将国内外相关 的研究焦点及今后需要加强的研究作简要分析。

\section{1 植物对 $\mathrm{O}_{3}$ 污染的敏感性}

$\mathrm{O}_{3}$ 污染会导致高产作物的高产性能消失, 甚至 使植物丧失遗传基础（Todd，1958; Rich，1964; Sagar, 1988 ; Pääkkönen et al. , 1997)。基于对食品 安全的考虑,各国学者大多以小麦( Triticum aestivum) (Shannon \& Mulchi , 1974 ; Kress et al., 1985 ; Heagle et al . , 1987 ; Pleijel et al . , 1991 ; Mulholland et al .,1997a)、大豆 (Glycine max) (Elagoz \& Manning, 2002 ; Morgan et al . 2003)、油菜( Brassica napus ssp. oleifera) (Ollerenshaw et al. , 1999) 等农作物作为研 究对象来研究 $\mathrm{O}_{3}$ 对植物生长的影响。

国内外研究人员多数采用开顶式同化箱 (Opentop chamber, OTC)熏蒸模拟处理, 针对近地面 $\mathrm{O}_{3}$ 浓 度升高对植物的影响进行了大量深入的研究。根据 $\mathrm{O}_{3}$ 熏蒸的时间和浓度, 可以将 $\mathrm{O}_{3}$ 熏蒸方式分为两 类㴔性短期 (数小时) 熏蒸 $\left(\mathrm{O}_{3}\right.$ 浓度 > $120 \mu \mathrm{g}$ $\left.\mathrm{kg}^{-1}\right)$ 慢性长期 (整个生长季节) 熏蒸 $\left(\mathrm{O}_{3}\right.$ 浓度 $<120$ $\mu \mathrm{g} \mathrm{kg}^{-1}$ )(Long \& Naidu ,2002)。前者可导致叶片上 表面出现诸如棕色、深紫色的可见伤害症状 (Guidi et al . ,2000) 以及其它生理生化效应; 后者有可能不 会对植物造成可见伤害 (Ollerenshaw \& Lyons， 1999）,但会诱导改变基因表达(Gupta et al. ,2005)、 改变生长速率 (Barnes et al. , 1990 ; Ollerenshaw \& Lyons，1999)、降低生态系统功能和减少生物多样性 (Miller \& McBride, 1999 ; Volk et al. ,2006)。

\section{1 决定植物敏感性的主要生物学特性}

$\mathrm{O}_{3}$ 对植物的伤害存在着累积效应 (Reich , 1987)。在单一生长季, 相同剂量的 $\mathrm{O}_{3}$ 胁迫对作物 特别是豆科植物的危害最大, 其次是阔叶树, 再次是 针叶树; 但在相同吸收剂量下, 所有植物受到的胁迫
程度基本相同 (Reich, 1987)。由于北半球 $\mathrm{O}_{3}$ 浓度 年变化的一个突出特点是最高峰出现在春季 5 月 （Vingarzan，2004）, 因此，生长季节集中在春季的作 物, 如冬小麦受到 $\mathrm{O}_{3}$ 污染的潜在危害相对较大 (Wang et al. , 2005)。与其它胁迫如干旱、高温等相 似 植物在生殖阶段对 $\mathrm{O}_{3}$ 的敏感性最大 (Pleijel et $a l$ ，1998)。另外, 研究表明, 短期高浓度 $\mathrm{O}_{3}$ 对植物 的伤害大于相同剂量的低浓度 $\mathrm{O}_{3}$ 所引发的伤害 (Meyer et al . 2000)。

植物对 $\mathrm{O}_{3}$ 的反应或敏感性取决于诸如叶片导 度、叶片结构及生化解毒等很多方面 (Matyssek et $a l$ ，，2004）。首先，叶片导度限制着植物对 $\mathrm{O}_{3}$ 的吸 收量, 因此, 叶片导度通常被认为是决定抗性最为重 要的因子 (Reich , 1987 ; Postiglione et al . , 2000 ;Elagoz et al. ,2006)。处于湿润条件下的植物, 通常 具有较高叶片导度, 其受到 $\mathrm{O}_{3}$ 危害的程度一般也较 大(Tingey et al. ,2001)。Pleijel 等 (2006) 通过研究 发现瑞典小麦新品种比老品种对 $\mathrm{O}_{3}$ 胁迫更敏感, 希 腊新老春小麦品种也具有相同的趋势 (Barnes et $a l$, 1990)。主要原因是新品种通常具有较高的气 孔导度 ( Pleijel et al, , 2006)。然而, Saitanis 和 Karandinos (2002) 研究了 7 种烟草品种对 $\mathrm{O}_{3}$ 敏感性 的反应, 指出烟草 (Nicotiana tabacum) 对 $\mathrm{O}_{3}$ 敏感性 的差异不能归因于气孔导度的不同。其次, 植物抗 氧化胁迫能力的大小也决定着其对 $\mathrm{O}_{3}$ 的敏感性。 同一植株的老叶首先表现出伤害症状, 这是由于老 叶的抗氧化能力比新叶差, 体现在抗坏血酸和谷胱 甘肽含量及抗坏血酸氧化物酶和谷胱甘肽还原酶活 性低于新叶(Bender et al. , 1994)。另外, 叶片对 $\mathrm{O}_{3}$ 的敏感程度与其叶片结构关系密切, 拥有较大的细 胞间隙对抗污染特性至关重要, 叶片上表面的栅栏 组织较海绵组织致密, 因此通常较早表现出伤害症 状 (Gravano et al. ,2003)。

\section{2 环境因子的影响}

影响植物对 $\mathrm{O}_{3}$ 反应的环境因子很多, 诸如光 照、湿度、温度等。由于 $\mathrm{O}_{3}$ 主要通过气孔进入植物 体内, 因此目前的研究主要集中在能显著调节气孔 导度的环境因子, 如土壤水分状况和在未来可能会 与大气中 $\mathrm{O}_{3}$ 浓度同步增加的 $\mathrm{CO}_{2}$ 浓度。

理论上, 土壤水分亏缺可降低植物的气孔导度， 减少 $\mathrm{O}_{3}$ 吸收量, 从而在很大程度上降低 $\mathrm{O}_{3}$ 对植物 的伤害 (King, 1988)。研究表明, 干旱在减轻 $\mathrm{O}_{3}$ 胁 迫对植物伤害方面的作用取决于干旱胁迫的强度以 及其它环境因子。在相对密闭的 OTC 中模拟 $\mathrm{O}_{3}$ 升 
高，干旱能够在很大程度上减轻 $\mathrm{O}_{3}$ 对植物的伤害， 而自然环境下, 干旱却加剧了高浓度 $\mathrm{O}_{3}$ 对植物的伤 害, 表现为气孔导度增大, 意味着干旱与 $\mathrm{O}_{3}$ 胁迫同 时存在时，可能会导致气孔控制水分的功能失调而 起不到保护 $\mathrm{O}_{3}$ 胁迫的作用 (Pääkkönen et al. , 1998)。Khan 和 Soja (2003) 的研究表明 水分充足条 件下, 小麦对 $\mathrm{O}_{3}$ 的吸收量增加, 而产量下降的幅度 减小; 小麦受到干旱胁迫后, 对 $\mathrm{O}_{3}$ 的吸收量减少, 但 产量降低的幅度依然增加; 只有当植株处于严重干 旱环境下，产量才将不再因 $\mathrm{O}_{3}$ 胁迫而降低。

众多研究表明, 大气 $\mathrm{CO}_{2}$ 浓度升高可显著降低 $\mathrm{O}_{3}$ 污染对植物的伤害 (McKee et al ., 1997 ; Mulholland et al. , 1997a ; Heagle et al. , 2000 ; Pleijel et al . , 2000 ; Tiedemann \& Firsching , 2000 ; Cardoso-Vilhena et al. , 2004)。Mulholland 等 (1997b) 研究了高 浓度 $\mathrm{CO}_{2}$ 与 $\mathrm{O}_{3}$ 对春小麦气体交换的交互作用, 发现 在春小麦营养生长期间，高浓度 $\mathrm{CO}_{2}$ 能够显著抑制 $\mathrm{O}_{3}$ 对其光合活性的抑制。其可能的一个主要原因 是高浓度 $\mathrm{CO}_{2}$ 可降低植物气孔导度, 从而减少了植 物对 $\mathrm{O}_{3}$ 的吸收量 (Cardoso-Vilhena et al , 2004) ;此 外, 高浓度 $\mathrm{CO}_{2}$ 可加强 Rubisco 酶的活性, 提高植物 的光合速率, 从而在某种程度上减轻了 $\mathrm{O}_{3}$ 对植物光 合作用的抑制; 同时, $\mathrm{CO}_{2}$ 浓度增加可改变叶片细胞 壁的化学组成, 如半纤维素的含量增加等 (Oksanen et al . 2005) ,从而提高植物对氧化胁迫的抗性。然 而, 研究人员发现, 高浓度 $\mathrm{CO}_{2}$ 虽能减轻 $\mathrm{O}_{3}$ 对小麦 营养生长的抑制但并不能够减轻 $\mathrm{O}_{3}$ 对小麦产量的 负效应(McKee et al. , 1997)。原因是, 在生殖生长 尤其是开花期间， $\mathrm{O}_{3}$ 可能对生殖过程如花粉萌发、 花粉管的生长、受精及胚的生长造成直接的伤害作 用, 导致高浓度 $\mathrm{CO}_{2}$ 减轻 $\mathrm{O}_{3}$ 胁迫对春小麦产量的效 应很小(Mulholland， et al，,1997b，1998)。

另外, 研究人员也针对养分 (特别是 N) 供给量 的多少在影响植物对 $\mathrm{O}_{3}$ 污染反应方面的作用进行 了大量研究。黑杨 (Populus trichocarpa) 在氮肥亏缺 条件下, 由 $\mathrm{O}_{3}$ 诱发的落叶是正常供氮条件下的两倍 (Bielenberg et al. ,2001)。植物生长期间氮素的供 给量可影响 $\mathrm{O}_{3}$ 对叶片衰老的诱导程度。Pääkkönen 和 Holopainen(1995) 通过研究不同氮肥供应条件下 垂枝桦 (Betula pendula) 克隆植株对 $\mathrm{O}_{3}$ 的反应, 发现 高氮能够提高植株对 $\mathrm{O}_{3}$ 的抗性。然而, Maurer 等 (1997)的研究发现,高营养并不能保证垂枝桦在 $O_{3}$ 胁迫下维持较高的光合活性, 也不能延迟 $\mathrm{O}_{3}$ 对叶片 衰老的诱导。其可能原因是高营养条件下, 植株的
机会成本”较大，即用于维持已受伤害叶片功能的 投资较少, 而主要是加快营养物质从衰老叶片中输 出, 促进新生叶的形成, 同时加强新生叶的光合能 力。

\section{$2 \mathrm{O}_{3}$ 对植物个体生理过程的影响}

$\mathrm{O}_{3}$ 主要是通过气孔扩散进入植物叶片细胞间 空隙, 溶解于与细胞壁结合的水中, 并经反应形成一 系列的活性氧自由基 (AOS)（Wohlgemuth et al. , 2002）,AOS 攻击细胞膜，导致细胞膜部分破裂，同时 细胞膜通过产生乙烯及茉莉酸等信号物质引起细胞 内发生一系列的改变 (Long \& Naidu，2002)。 $\mathrm{O}_{3}$ 对 植物的生物学效应不仅取决于环境中的 $\mathrm{O}_{3}$ 浓度, 而 且取决于植物所吸收的 $\mathrm{O}_{3}$ 量以及植物抗氧化能力 的大小(Tausz et al. ,2007)。

\section{1 对植物气孔导度的影响}

气孔是植物体与外界气体交换的 大门”, 是 $\mathrm{O}_{3}$ 进入植物体的主要通道, 控制着蒸腾、光合、呼吸等 重要生理过程。因此, 高浓度 $\mathrm{O}_{3}$ 可能会改变植物气 孔的可塑性 (Elagoz et al. , 2006) , 改变气孔导度大 小 将对植物生长发育产生深远影响。

通常，高浓度 $\mathrm{O}_{3}$ 环境下，植物表现出较低的气 孔导度(Pääkkönen et al ，,1998)。但研究表明，对 $\mathrm{O}_{3}$ 敏感性不同的植物其气孔导度对 $\mathrm{O}_{3}$ 的反应程度不 同 (Elagoz et al ., 2006)。Reiling 和 Davison(1995)研 究了英国 28 个大车前草 (Plantago major) 种群发现， 在 $\mathrm{O}_{3}\left(70 \mu \mathrm{g} \mathrm{kg}{ }^{-1}\right)$ 熏蒸初始的几个小时内, 所有种 群的气孔导度均降低，对 $\mathrm{O}_{3}$ 敏感的种群表现得尤为 明显, 随着熏蒸时间的延长, $\mathrm{O}_{3}$ 对气孔导度的降低 效应逐渐减小, 且敏感种群较抗性种群改变幅度大。 Hassan 等 (1994) 对埃及夢卜 (Raphanus sativus cv. Baladey)和芜菁 (Brassica rapa cv. Sultani) 的研究表 明，在高 $\mathrm{O}_{3}$ 浓度 $\left(80 \mu \mathrm{g} \mathrm{kg}{ }^{-1}\right)$ 下, 两物种的光合速率 都显著降低，但二者的气孔导度反应截然相反，芜等 的气孔导度降低，而埃及萝卜升高; 通过不同浓度 的 $\mathrm{O}_{3}$ 熏蒸试验也证实埃及夢卜光合速率随 $\mathrm{O}_{3}$ 浓度 升高而降低, 而气孔导度却随 $\mathrm{O}_{3}$ 浓度升高而升高。

$\mathrm{O}_{3}$ 对气孔的作用将影响植物生产力, 同时也将 影响植物对其它环境胁迫如干旱等的反应, 因此, 学 者们对 $\mathrm{O}_{3}$ 影响植物气孔导度的机理进行了深入探 讨。Hassan 等(1994)通过扫描电镜 (Scanning electron microscopy, SEM) 观察发现高浓度 $\mathrm{O}_{3}$ 引发埃及萝卜 表皮细胞部分破裂，从而导致气孔开放率增大而气 
孔导度增加。 $\mathrm{O}_{3}$ 也可直接抑制保卫细胞的 $\mathrm{K}^{+}$通 道，降低 $\mathrm{K}^{+}$通道调控气孔开张的能力 (Torsethaugen et al . , 1999)。另外, 高浓度 $\mathrm{O}_{3}$ 环境下植物为维持 相对稳定的胞间 $\mathrm{CO}_{2}$ 浓度而降低气孔导度, 同时气 孔导度的变化与叶肉细胞内其它过程的变化相偶联 (Noormets et al. , 2001) , 也是植物气孔导度降低的 一个原因。

\section{2 对植物光合作用的影响}

$\mathrm{O}_{3}$ 对植物光合作用的影响备受关注, 研究相对 较多。 $\mathrm{O}_{3}$ 的强氧化性导致高浓度 $\mathrm{O}_{3}$ 环境中植物的 光合速率下降, 这已经得到大量实验证实( Farage \& Long , 1992 ; Reiling \& Davison , 1995 ; Mulholland et al. , 1997b ; Ewert \& Porter, 2000 ; Noormets et al. , 2001)。

Leipner 等 (2001) 利用具有高分辨率的叶绿素荧 光成像系统研究了短期高浓度 $\mathrm{O}_{3}$ 熏蒸处理 (250 $500 \mu \mathrm{g} \mathrm{kg}^{-1}, 3 \mathrm{~h}$ )对植物叶片不同部位光合能力的 影响, 指出 $\mathrm{O}_{3}$ 通过气孔进入叶片后, 首先影响靠近 气孔的细胞的光合作用。Meyer 等 (2000) 利用 110 $\mu \mathrm{g} \mathrm{kg}{ }^{-1} \mathrm{O}_{3}$ 熏蒸小麦后, 发现短时间处理导致叶片 细胞膜系统受损, 光合产物输出受阻; 而长期受 $\mathrm{O}_{3}$ 污染后, 小麦叶片的光合速率、光化学效率、叶绿素 含量和熫糖含量均显著降低, 并与 $\mathrm{O}_{3}$ 剂量的大小和 峰值出现的早晚有关。

高浓度 $\mathrm{O}_{3}$ 环境下 植物光合作用降低的生理原 因, 主要是 $\mathrm{O}_{3}$ 导致叶绿素和可溶性蛋白分解, 叶片 衰老加快 (Gelang et al . ,2000)、叶绿体结构发生改 变( Kivimaenpaa et al . , 2005)、活性氧清除酶和与碳 素固定有关的酶活性降低 (Reichenauer \& Goodman , 2001)、光合产物向外运输受阻而导致的反馈抑制 (Einig et al ., 1997 ; Grantz \& Farrar , 1999)。长期 $O_{3}$ 胁迫可诱发乙烯的生成, 产生衰老信号, 导致叶片早 衰(Pell et al. , 1997) ;研究表明乙烯生产量的多少 直接关系到 $\mathrm{O}_{3}$ 伤害症状包括光合作用下降程度的 大小(Sinn et al. ,2004)。

$\mathrm{O}_{3}$ 胁迫对叶片的光合效应还取决于叶龄 (Saxe， 1991)。首先 新叶保护和修复 $\mathrm{O}_{3}$ 伤害的能力较强; 其次, $\mathrm{O}_{3}$ 对不同叶龄叶片中的 Rubisco 酶的含量可 能产生不同的影响。研究表明, 高浓度 $\mathrm{O}_{3}$ 环境下, 老叶中的 Rubisco 酶的合成几乎未受到影响，而该酶 的降解酶活性升高，从而导致叶片中 Rubisco 酶的含 量降低; 新叶中 Rubisco 酶的含量及合成速度都受 $\mathrm{O}_{3}$ 的刺激而增大。研究人员指出, 不同叶龄叶片的
这种反应可能是植株对所受伤害的一种补偿机制 (Brendley \& Pell , 1998)。

\section{3 对植物同化物分配的影响}

短期高浓度 $\mathrm{O}_{3}$ 熏蒸导致小麦叶面积指数降低 9\%，虽然根系干重的降低并不显著，但根系向土壤 分泌的 $\mathrm{C}$ 增加, 长期生长在高 $\mathrm{O}_{3}$ 环境下的植物根冠 比显著降低 (McCrady \& Andersen, 2000 ; Grantz et $a l$ ，2006)。研究表明, $\mathrm{O}_{3}$ 环境下, 植物叶片厚度降 低, 棚栏组织和海绵组织的比率增大, 过氧化物酶体 和线粒体的数量增加 (Oksanen et al . ,2004, 2005); 叶片细胞中与抗氧化胁迫有关的次生代谢物质如绿 原酸 (Chlorogenic acid)、黄酮 (Flavone aglycons) 等的 含量增加 (Peltonen et al. , 2005 ; Sallas et al. , 2001)。Gupta 等 (2005) 研究了颤杨 (Populus tremuloides ) 在经历了 5 年 $\mathrm{O}_{3}$ 熏蒸后基因的表达, 结果表 明与信号转导及防御相关的基因表达增强, 而与光 合作用以及能量相关的基因表达被削弱,指出高浓 度 $\mathrm{O}_{3}$ 可诱导植物基因表达向着信号转导及防御的 方向改变, 诱导植物产生抗氧化胁迫的次生代谢物 质以及抗氧化物质。白月明等 (2001) 用高浓度 $\mathrm{O}_{3}$ 熏蒸拔节前的冬小麦, 发现小麦春季分覧数量增加, 然而随着 $\mathrm{O}_{3}$ 胁迫时间的延长大部分新生分藍逐渐 枯死。由此可见环境中 $\mathrm{O}_{3}$ 浓度升高可引起植物光 合产物的分配发生巨大改变。

光合产物分配改变的原因主要有:一是植物叶 片作为碳源的能力降低。植物叶片是 $\mathrm{O}_{3}$ 攻击的直 接位点, $\mathrm{O}_{3}$ 可改变气孔功能, 从而改变植株的同化 能力和水分利用效率; 同时, $\mathrm{O}_{3}$ 可降低光合酶的数 量和活性, 加快叶绿素降解、导致光合有效叶面积的 减少以及叶片的早衰, 从而显著降低了植株的光合 能力。二是叶片作为碳库增加了对同化物的需求。 高浓度 $\mathrm{O}_{3}$ 胁迫下, 叶肉细胞尤其是栅栏组织的损伤 引发植株修复代谢消耗的增加; 同时, 抗氧化系统的 增强必然增加叶片对同化物的需求。另外, 研究还 表明 $\mathrm{O}_{3}$ 可能对韧皮部组织有直接的作用, 导致同化 物向外运输的能力降低 (Grantz \& Farrar，1999)，从 而导致叶片中同化产物的积累, 进而引起光合的反 馈抑制。

$\mathrm{O}_{3}$ 污染首先加快老叶的衰老,而对新叶的影响 很小。老叶衰老能够将其中的营养转移到新生长叶 片中, 有利于维持植株的生长。研究发现, $\mathrm{O}_{3}$ 环境 下 老叶迅速衰老的同时, 同一植株中的新生组织由 于具有较高的 Rubisco 合成速率和总量 (Brendley \& Pell , 1998) ,同化速率反而得到了加强( Pell et al. , 
1994)。这一现象被认为是植株在 $\mathrm{O}_{3}$ 环境下的一种 补偿机制(Pell et al. , 1994)。

$\mathrm{O}_{3}$ 显著降低植株同化物向根系的分配 (Andersen ,2003; McCrady \& Andersen，2000) ,而同化物向 根系分配的改变将导致根系与整株植物功能关系的 改变。在水分亏缺环境下, $\mathrm{O}_{3}$ 通过降低茎的水分状 况而提高植株对水分亏缺的敏感性，如 $\mathrm{O}_{3}$ 胁迫加强 了水分亏缺对大豆的效应(Heggestad et al .,1988)。 植物根系的生长受到抑制, 导致根系对土壤营养吸 收能力的降低，从而间接降低叶片的光合速率。

从作物产量方面来看, $\mathrm{O}_{3}$ 胁迫对同化物的分配 效应比其对光合作用及生物量积累的负影响更为重 要(McKee \& Long，2001)。而对于野生植物来讲，同 化物分配的改变较之生物量将具有更重要的生态学 意义(Davison \& Barnes , 1998)。

\section{$3 \mathrm{O}_{3}$ 污染对物种间相互关系的作用及生物 多样性的影响}

不同植物对 $\mathrm{O}_{3}$ 的反应不同，因此, $\mathrm{O}_{3}$ 胁迫势必 在一定程度上改变植物种间的相互关系。尽管目前 $\mathrm{O}_{3}$ 胁迫对群落及物种间关系的研究相对较少, 但已 有的研究报道表明 $\mathrm{O}_{3}$ 胁迫可改变群落的生物多样 性。

由于豆科植物对 $\mathrm{O}_{3}$ 胁迫的敏感性大于 $\mathrm{C}_{3}$ 及 $\mathrm{C}_{4}$ 植物, 在高浓度 $\mathrm{O}_{3}$ 环境下, 豆科植物生物量降低幅 度较大且物种减少较多 (Volk et al. ,2006)。 $\mathrm{O}_{3}$ 胁 迫可改变物种间的竞争关系, 且因植物对 $\mathrm{O}_{3}$ 敏感程 度而异。如在高浓度 $\mathrm{O}_{3}$ 环境下, 由于 $\mathrm{O}_{3}$ 对具有抗 性的 $\mathrm{C}_{4}$ 杂草一一莎草 (Cyperus esculentus) 产生的生 长抑制作用较小, 而对 $\mathrm{O}_{3}$ 相对敏感的西红柿 ( $L y-$ copersicon esculentum) 的生长抑制显著，因此，西红柿 植株的竞争力将被削弱; 同时, 该杂草将同化物主要 分配于生殖器官, 由此将增加未来高浓度 $\mathrm{O}_{3}$ 环境下 杂草控制的难度 (Shrestha \& Grantz, 2005)。Kozovits 等(2005) 对具有不同竞争力的欧洲水青冈 ( Fagus sylvatica) 和云杉 (Picea abies) 幼树的研究也得出相似 的结论，即对 $\mathrm{O}_{3}$ 敏感同时竞争力较弱的欧洲水青冈 幼树受到 $\mathrm{O}_{3}$ 胁迫的负效应较大, 而对 $\mathrm{O}_{3}$ 不敏感且 竞争力较强的云杉却能从与欧洲水青冈的竞争中获 益,因而受 $\mathrm{O}_{3}$ 胁迫的影响较小。

由于 $\mathrm{O}_{3}$ 胁迫后植物生长相对较弱且可能表现 出可见伤害症状, 叶片表面湿度增大, 因此容易感染 病菌。如 $\mathrm{O}_{3}$ 胁迫增加了颤杨对叶锈病 (Melampsora medusae f. sp. tremuloidae) 的感染 ( $3 \sim 5$ 倍)
(Karnosky et al ，2002)，而且对 $\mathrm{O}_{3}$ 敏感的颤杨克隆 植株受到感染的机率更大(Karnosky et al. , 2005)。 $\mathrm{O}_{3}$ 可抑制小麦叶锈病 (Puccinia recondita f. sp. triti$c i$ 的发生, 然而 $\mathrm{O}_{3}$ 对已感染锈病的小麦叶片的伤 害较健康叶片重( Tiedemann \& Firsching, 2000)。由 于 $\mathrm{O}_{3}$ 胁迫后植物叶片的次生代谢物质 (Yamaji et al ，，2003）及营养成分 (Hamilton et al.，2005) 发生 了改变, 导致害虫的发生或降低(Kopper \& Lindroth， 2003a)或增加 (Kopper \& Lindroth, 2003b ; Hamilton et al. ,2005)。

高浓度 $\mathrm{O}_{3}$ 环境下 植物向土壤供给的凋落物减 少, 并且调落物的组成发生了改变, 这将对土壤微生 物的生物量及活性产生显著负效应 (Holmes et al. , 2003 ）,由此将对地下生态过程产生很大影响, 导致 整个生态系统的特性也将因此而发生改变 (Andersen , 2003)。大气中 $\mathrm{O}_{3}$ 和 $\mathrm{CO}_{2}$ 浓度同时增加 $50 \%$ 时 , 土壤中总 $\mathrm{C}$ 和酸不溶性 $\mathrm{C}$ 的形成比仅增加 $\mathrm{CO}_{2}$ 浓度低 50\% (Loya et al，，2003）。因此, $\mathrm{O}_{3}$ 浓度增 加将抵消未来 $\mathrm{CO}_{2}$ 浓度增高可能增加的土壤 $\mathrm{C}$ 的 量。

\section{4 结语与展望}

不同植物以及同一植物种的不同品种对 $\mathrm{O}_{3}$ 的 敏感性存在很大差异, 因此, 比较并选择在当前以及 未来全球变化环境下对 $\mathrm{O}_{3}$ 具有较高抗性的作物品 种, 同时研究不同植物对 $\mathrm{O}_{3}$ 响应的机理, 可指导预 防和减轻植物尤其是作物因 $\mathrm{O}_{3}$ 胁迫而带来的负面 影响。这应是我国科研工作者今后所要开展的主要 研究工作。

喷施植物生长调节剂如乙烯利 (McKee \& Long ， 2001 )、抗氧化物质如外源抗坏血酸 (Exogenous ascorbate acid，ExAsA）(郑启伟等，2006），及能够提高植 物抗氧化酶活性/量的外源物质如 Ethylenediurea (EDU) (Tiwari et al . ,2005 ; Hassan , 2006 ; Paoletti et $a l$. ,2006) 等都能够显著减轻 $\mathrm{O}_{3}$ 对植物的伤害。预 示着 $\mathrm{O}_{3}$ 对植物的危害可以通过栽培管理进行调控。 因此, 如何采用合理的栽培管理措施, 提高植物对 $\mathrm{O}_{3}$ 的适应性和抗性, 使 $\mathrm{O}_{3}$ 危害降到最低点, 应作为 今后深入研究的内容之一。

相比作物而言, 野生植物对 $\mathrm{O}_{3}$ 胁迫的响应以及 由此引起的种间关系的改变还了解甚少。由于自然 生态系统在生态安全中的重要性, 因此必须加强研 究野生植物和自然植被在 $\mathrm{O}_{3}$ 污染影响下的反应趋 势, 这也将为建设我国的生态安全提供理论依据。 
虽然植物吸收空气中的 $\mathrm{O}_{3}$ 后会对自身产生伤 害, 但同时也降低了空气中的 $\mathrm{O}_{3}$ 浓度。据我国台湾 省中华农学会 1999 年的报道, 水稻(Oryza sativa) 田 可以使其上方的空气中 $\mathrm{O}_{3}$ 浓度降低 $11 \%$ 左右。随 着我国汽车持有量每年以 $9.3 \%$ 的速度递增, $\mathrm{NO}_{\mathrm{x}}$ 和 VOCs 排放量增加, 大气中的 $\mathrm{O}_{3}$ 浓度也将随之升高。 如何充分发挥绿色植被在治理 $\mathrm{O}_{3}$ 污染中的作用需 要进一步研究。

\section{参 考 文 献}

Adams R, Hamilton S, McCarl B (1985). An assessment of the economic effects of ozone on U.S. agriculture. Journal of Air Pollution Control Association, 35, 938 - 943.

Andersen CP (2003). Source-sink balance and carbon allocation below ground in plants exposed to ozone. New Phytologist, 157, $213-228$.

Bai YM (白月明), Huo ZG (霍治国), Wang CY (王春乙), Guo JP (享建平), Wen M (温民) (2001). Trial study on the effects of elevated ozone concentration on winter wheat leaf. Chinese Journal of Agrometeorology (中国农业气象), 22 (4), 22 - 27. (in Chinese with English abstract)

Barnes JD, Velissariou D, Devison AW, Holevas CD ( 1990 ). Comparative ozone sensitivity of old and modern Greek cultivars of spring wheat. New Phytologist, 6, 707 - 714.

Bender J, Weigel HJ, Wegner U, Jager HJ (1994). Response of cellular antioxidants to ozone in wheat flag leaves at different stages of plant development. Environmental Pollution, 84, 15 21 .

Bielenberg DG, Lynch JP, Pell EJ (2001) . A decline in nitrogen availability affects plant responses to ozone. New Phytologist, $151,413-425$.

Brendley BW, Pell EJ (1998). Ozone-induced changes in biosynthesis of Rubisco and associated compensation to stress in foliage of hybrid poplar. Tree Physiology, 18, $81-90$.

Cardoso-Vilhena J, Balaguer L, Eamus D, Ollerenshaw J, Barnes J (2004). Mechanisms underlying the amelioration of $\mathrm{O}_{3}$-induced damage by elevated atmospheric concentrations of $\mathrm{CO}_{2}$. Journal of Experimental Botany, 55, 771 - 781 .

Davison AW, Barnes JD (1998). Effects of ozone on wild plants. New Phytologist, 139, 135 - 151 .

Elagoz V, Manning WJ (2002). Ozone and bean plants: morphology matters. Environmental Pollution, 120, 521.

Elagoz V, Han SS, Manning WJ (2006). Acquired changes in stomatal characteristics in response to ozone during plant growth and leaf development of bush beans (Phaseolus vulgaris L.) indicate phenotypic plasticity. Environmental Pollution, 140, 395.

Einig W, Lauxmann U, Hauch B, Hampp R, Landolt W, Maurer S, Matyssek R (1997). Ozone-induced accumulation of carbohydrates changes enzyme activities of carbohydrate metabolism in birch leaves. New Phytologist, 137, 673-680.
Ewert F, Porter JR (2000) . Ozone effects on wheat in relation to $\mathrm{CO}_{2}$ : modelling short-term and long-term responses of leaf photosynthesis and leaf duration. Global Change Biology, 6, 735 750 .

Farage PK, Long SP (1992). Ozone inhibition of photosynthesis-a mechanistic analysis following short-term and long-term exposure in 3 contrasting species. Photosynthesis Research, 34, 244 254 .

Felzer BS, Kicklighter DW, Melillo JM, Wang C, Zhuang Q, Prinn RG (2004) . Effects of ozone on net primary production and carbon sequestration in the conterminous United States using a biogeochemistry model. Tellus $B, 56,230-248$.

Feng ZW, Jin MH, Zhang FZ, Huang YZ (2003). Effects of ground-level ozone $\left(\mathrm{O}_{3}\right)$ pollution on the yields of rice and winter wheat in the Yangtze River Delta. Journal of Environmental Sciences, $15,360-362$.

Gelang J, Pleijel H, Sild E, Danielsson H, Younis S, Selldén G (2000) . Rate and duration of grain filling in relation to flag leaf senescence and grain yield in spring wheat (Triticum aestivum) exposed to different concentrations of ozone. Physiologia Plantarum, $110,366-375$.

Grantz D, Farrar J (1999) . Acute exposure to ozone inhibits rapid carbon translocation from source leaves of Pima cotton. Journal of Experimental Botany, 50, 1253 - 1262.

Grantz DA, Gunn S, Vu HB (2006). O 3 impacts on plant development: a meta-analysis of root/shoot allocation and growth. Plant, Cell and Environment, 29, 1193 - 1209.

Gravano E, Giulietti V, Desotgiu R, Bussotti F, Grossoni P, Gerosa G, Tani C (2003). Foliar response of an Ailanthus altissima clone in two sites with different levels of ozone-pollution. Environmental Pollution, 121, 137 - 146.

Guidi L, Cagno RD, Soldatini GF (2000). Screening of bean cultivars for their response to ozone as evaluated by visible symptoms and leaf chlorophyll fluorescence. Environmental Pollution, 107, $349-355$.

Gupta P, Duplessis S, White H, Karnosky DF, Martin F, Podila GK (2005). Gene expression patterns of trembling aspen trees following long-term exposure to interacting elevated $\mathrm{CO}_{2}$ and tropospheric $\mathrm{O}_{3}$. New Phytologist, 167, 129-142.

Hamilton JG, Dermody O, Aldea M, Zangerl AR, Rogers A, Berenbaum MR, DeLucia EH (2005). Anthropogenic changes in tropospheric composition increase susceptibility of soybean to insect herbivory. Environmental Entomology, 34, 479 - 485 .

Hassan IA, Ashmore MR, Bell JNB (1994). Effects of $\mathrm{O}_{3}$ on the stomatal behaviour of Egyptian varieties of radish (Raphanus sativus L. cv. Baladey) and turnip (Brassica rapa L. cv. Sultani). New Phytologist, 128, 243-249.

Hassan IA (2006) . Physiological and biochemical response of potato (Solanum tuberosum L. cv. Kara) to $\mathrm{O}_{3}$ and antioxidant chemicals : possible roles of antioxidant enzymes. Annals of Applied Biology, 148, $197-206$. 
Heagle AS, Miller JE, Pursley WA (2000). Growth and yield responses of winter wheat to mixtures of ozone and carbon dioxide. Crop Science, 40, 1656 - 1664.

Heagle AS, Flagler RB, Patterson RP, Lesser VM, Shafer SR, Heck WW (1987). Injury and yield response of soybean to chronic doses of ozone and soil moisture deficit. Crop Science, $27,1016-1024$.

Heggestad HE, Anderson EL, Gish TJ, Lee EH (1988). Effects of ozone and soil water deficit on roots and shoots of field-grown soybeans. Environmental Pollution, 50, 259 - 278.

Holmes WE, Zak DR, Pregitzer KS, King JS (2003). Soil nitrogen transformations under Populus tremuloides, Betula papyrifera and Acer saccharum following 3 years exposure to elevated $\mathrm{CO}_{2}$ and $\mathrm{O}_{3}$. Global Change Biology, 9, 1743 - 1750 .

Karnosky DF, Percy KE, Xiang B, Callan B, Noormets A, Mankovska B, Hopkin A, Sober J, Jones W, Dickson RE, Isebrands JG (2002). Interacting elevated $\mathrm{CO}_{2}$ and tropospheric $\mathrm{O}_{3}$ predisposes aspen (Populus tremuloides Michx.) to infection by rust (Melampsora medusae f. sp. tremuloidae). Global Change Biology, 8, 329 - 338 .

Karnosky DF, Pregitzer KS, Zak DR, Kubiske ME, Hendrey GR, Weinstein D, Nosal M, Percy KE (2005). Scaling ozone responses of forest trees to the ecosystem level in a changing climate. Plant, Cell and Environment, 28, 965 - 981 .

Khan S, Soja G (2003). Yield responses of wheat to ozone exposure as modified by drought-induced differences in ozone uptake. Water, Air, and Soil Pollution, 147, 299-315.

King DA (1988) . Modeling the impact of ozone x drought interactions on regional crop yields. Environmental Pollution, 53, $351-364$.

Kivimaenpaa M, Sellden G, Sutinen S (2005). Ozone-induced changes in the chloroplast structure of conifer needles, and their use in ozone diagnostics. Environmental Pollution, 137, $466-$ 475 .

Kopper BJ, Lindroth RL (2003a). Responses of trembling aspen (Populus tremuloides) phytochemistry and aspen blotch leafminer (Phyllonorycter tremuloidiella) performance to elevated levels of atmospheric $\mathrm{CO}_{2}$ and $\mathrm{O}_{3}$. Agricultural and Forest Entomology, 5, $17-26$.

Kopper BJ, Lindroth RL (2003b) . Effects of elevated carbon dioxide and ozone on the genotypic response of aspen phytochemistry and the performance of an herbivore. Oecologia, 134, 95-103.

Kozovits AR, Matyssek R, Blaschke H, Gottlein A, Grams TEE (2005) . Competition increasingly dominates the responsiveness of juvenile beech and spruce to elevated $\mathrm{CO}_{2}$ and/or $\mathrm{O}_{3}$ concentrations throughout two subsequent growing seasons. Global Change Biology, 11, 1387 - 1401 .

Kress LW, Miller JE, Smith HJ (1985). Impact of ozone on winter wheat yield. Environmental and Experimental Botany, 25, 211 228 .

Leipner J, Oxborough K, Baker NR (2001). Primary sites of o- zone-induced perturbations of photosynthesis in leaves: identification and characterization in Phaseolus vulgaris using high resolution chlorophyll fluorescence imaging. Journal of Experimental Botany, 52, $1689-1696$.

Liu JD (刘建栋), Zhou XJ (周秀䩀), Yu Q (于强), Yan P (颜 鹏), Guo JP (郭建平), Ding GA (丁国安) (2003). Numerical simulation of ground-level ozone effects on photosynthesis of rice. Acta Scientiae Circumstantiae (环境科学学报), 23, 289 - 294. (in Chinese with English abstract)

Long SP, Naidu SL (2002) . Effects of Oxidants at the Biochemical, Cell and Physiological Levels. John Wiley, London, UK.

Loya WM, Pregitzer KS, Karberg NJ, King JS, Giardina CP (2003) . Reduction of soil carbon formation by tropospheric ozone under increased carbon dioxide levels. Nature, 425, 705 .

Matyssek R, Wieser G, Nunn AJ, Kozovits AR, Reiter IM, Heerdt C, Winkler JB, Baumgarten M, Haberle KH, Grams TEE (2004) . Comparison between AOT40 and ozone uptake in forest trees of different species, age and site conditions. Atmospheric Environment, 38, 2271 - 2281 .

Maurer S, Matyssek R, Günthardt-Goerg M, Landolt W, Einig W (1997) . Nutrition and the ozone sensitivity of birch (Betula pendula). I. Responses at the leaf level. Trees Structure and Function, 12, $1-10$.

McCrady JK, Andersen CP (2000). The effect of ozone on belowground carbon allocation in wheat. Environmental Pollution, $107,465-472$.

McKee IF, Bullimore JF, Long SP (1997). Will elevated $\mathrm{CO}_{2}$ concentrations protect the yield of wheat from $\mathrm{O}_{3}$ damage? Plant, Cell and Environment, 20, $77-84$.

McKee IF, Long SP (2001). Plant growth regulators control ozone damage to wheat yield. New Phytologist, 152, $41-51$.

Meyer U, Kollner B, Willenbrink J, Krause GHM (2000). Effects of different ozone exposure regimes on photosynthesis, assimilates and thousand grain weight in spring wheat. Agriculture, Ecosystems and Environment, 78, 49-55.

Miller PR, McBride JR (1999). Oxidant Air Pollution Impacts in the Montane Forests of Southern California: a Case Study of the San Bernardino Mountains. Ecological Studies, Vol. 134. Springer-Verlag, New York.

Morgan PB, Ainsworth EA, Long SP (2003). How does elevated ozone impact soybean? A meta-analysis of photosynthesis, growth and yield. Plant, Cell and Environment, 26, 1317 - 1328 .

Mulholland B, Craigon J, Black C, Colls J, Atherton J, Landon G (1997a). Effects of elevated carbon dioxide and ozone on the growth and yield of spring wheat (Triticum aestivum L.) . Journal of Experimental Botany, 48, 113 - 122 .

Mulholland B, Craigon J, Black C, Colls J, Atherton J, Landon G (1997b). Impact of elevated atmospheric $\mathrm{CO}_{2}$ and $\mathrm{O}_{3}$ on gas exchange and chlorophyll content in spring wheat (Triticum aestivum L. ). Journal of Experimental Botany, 48, 1853 - 1863.

Mulholland BJ, Craigon J, Black CR, Colls JJ, Atherton J, Landon 
$\mathrm{G}$ (1998). Effects of elevated $\mathrm{CO}_{2}$ and $\mathrm{O}_{3}$ on the rate and duration of grain growth and harvest index in spring wheat ( Triticum aestivum L. ). Global Change Biology, 4, 627 - 635.

Noormets A, Sober A, Pell EJ, Dickson RE, Podila GK, Sober J, Isebrands JG, Karnosky DF (2001). Stomatal and non-stomatal limitation to photosynthesis in two trembling aspen (Populus tremuloides Michx.) clones exposed to elevated $\mathrm{CO}_{2}$ and/or $\mathrm{O}_{3}$. Plant, Cell and Environment, 24, 327 - 336.

Oksanen E, Haikio E, Sober J, Karnosky DF (2004). Ozone-induced $\mathrm{H}_{2} \mathrm{O}_{2}$ accumulation in field-grown aspen and birch is linked to foliar ultrastructure and peroxisomal activity. New Phytologist, $161,791-799$.

Oksanen E, Riikonen J, Kaakinen S, Holopainen T, Vapaavuori E (2005). Structural characteristics and chemical composition of birch (Betula pendula) leaves are modified by increasing $\mathrm{CO}_{2}$ and ozone. Global Change Biology, 11, $732-748$.

Ollerenshaw JH, Lyons T (1999). Impacts of ozone on the growth and yield of field-grown winter wheat. Environmental Pollution, $106,67-72$.

Ollerenshaw JH, Lyons T, Barnes JD (1999). Impacts of ozone on the growth and yield of field-grown winter oilseed rape. Environmental Pollution, 104, 53 - 59.

Pääkkönen E, Holopainen T (1995). Influence of nitrogen supply on the response of clones of birch (Betula pendula Roth. ) to ozone. New Phytologist, 129, 595-603.

Pääkkönen E, Holopainen T, Kärenlampi L (1997). Differences in growth, leaf senescence and injury, and stomatal density in birch (Betula pendula Roth. ) in relationship to ambient levels of ozone in Finland. Environmental Pollution, 96, 117 - 127.

Pääkkönen E, Vahala J, Pohjolal M, Holopainen T, Kärenlampi L (1998) . Physiological, stomatal and ultrastructural ozone responses in birch (Betula pendula Roth.) are modified by water stress. Plant, Cell and Environment, 21, 671-684.

Paoletti E, Manning WJ, Spaziani F, Tagliaferro F (2007) . Gravitational infusion of ethylenediurea (EDU) into trunks protected adult European ash trees (Fraxinus excelsior L.) from foliar ozone injury. Environmental Pollution, 145, 869-873.

Pearce F (2002). Smog crop damage costs billions. http: //www. newscientist . com/article. ns? id = dn2387. cited \ June 2002

Peltonen PA, Vapaavuori E, Julkunen-tiitto R (2005). Accumulation of phenolic compounds in birch leaves is changed by elevated carbon dioxide and ozone. Global Change Biology, 11, 1305 1324.

Pell EJ, Schlagnhaufer CD, Arteca RN (1997) . Ozone-induced oxidative stress: mechanisms of action and reaction. Physiologia Plantarum, 100, $264-273$.

Pell EJ, Temple PJ, Friend AL, Mooney HA, Winner WE (1994) . Compensation as a plant response to ozone and associated stresses: an analysis of ROPIS experiments. Journal of Environmental Quality, 23, 429-436.

Pleijel H, Danielsson H, Gelang J, Sild E, Selldén G (1998).
Growth stage dependence of the grain yield response to ozone in spring wheat (Triticum aestivum L.). Agriculture, Ecosystems and Environment, 70, 61-68.

Pleijel H, Danielsson H, Karlsson GP, Gelang J, Karlsson PE, Selldén G (2000). An ozone flux-relationship for wheat. Environmental Pollution, 109, 453 - 462 .

Pleijel H, Eriksen AB, Danielsson H, Bondesson N, Sellden G (2006). Differential ozone sensitivity in an old and a modern Swedish wheat cultivar-grain yield and quality, leaf chlorophyll and stomatal conductance. Environmental and Experimental Botany, 56, 63-71.

Pleijel H, Gelang J, Sild E, Danielsson H, Younis S, Karlsson PE, Wallin G, Skarby L, Sellden G (2000). Effects of elevated carbon dioxide, ozone and water availability on spring wheat growth and yield. Physiologia Plantarum, 108, 61-70.

Pleijel H, Skarby L, Wallin G, Sellden G (1991). Yield and grain quality of spring wheat (Triticum aestivum L. cv. Drabant) exposed to different concentrations of ozone in open-top chambers. Environmental Pollution, 69, 151 - 168 .

Postiglione L, Fagnano M, Merola G (2000). Response to ambient ozone of two white clover (Trifolium repens L. cv." Regal”) clones, one resistant and one sensitive, grown in a Mediterranean environment. Environmental Pollution, 109, 525 - 531 .

Reich PB (1987). Quantifying plant response to ozone: a unifying theory. Tree Physiology, 3, 63-91.

Reichenauer T, Goodman L (2001). Stable free radicals in ozonedamaged wheat leaves. Free Radical Research, 35, 93 - 101 .

Reiling K, Davison A (1995). Effects of ozone on stomatal conductance and photosynthesis in populations of Plantago major L. New Phytologist, 129, 587 - 594.

Rich S (1964). Ozone damage to plants. Annual Reviews of Phytopathology, 2, 253-266.

Ryerson T, Trainer M, Holloway J, Parrish D, Huey L (2001). Observations of ozone formation in power plant plumes and implications for ozone control strategies. Science, 292, 719-723.

Sagar V (1988). Plant injury induced by ozone. Environmental Pollution, 50, $101-137$.

Saitanis CJ, Karandinos MG (2002). Effects of ozone on tobacco (Nicotiana tabacum L.) varieties. Journal of Agronomy and Crop Science, 188, $51-58$.

Sallas L, Kainulainen P, Utriainen J, Holopainen T, Holopainen JK (2001). The influence of elevated $\mathrm{O}_{3}$ and $\mathrm{CO}_{2}$ concentrations on secondary metabolites of Scots pine (Pinus sylvestris L.) seedlings. Global Change Biology, 7, 303-311.

Saxe H (1991). Photosynthesis and stomatal responses to polluted air, and the use of physiological and biochemical responses for early detection and diagnostic tools. Advances in Botanical Research, 18, 1- 128 .

Shannon JG, Mulchi CL (1974). Ozone damage to wheat varieties at anthesis. Crop Science, 14, 355-357.

Shrestha A, Grantz DA (2005) . Ozone impacts on competition be- 
tween tomato and yellow nutsedge: above- and below-ground effects. Crop Science, 45, 1587 - 1595.

Sinn JP, Schlagnhaufer CD, Arteca RN, Pell EJ (2004) . Ozoneinduced ethylene and foliar injury responses are altered in 1aminocyclopropane-1-carboxylate synthase antisense potato plants. New Phytologist, 164, $267-277$.

Tang X, Li J, Chen D (1995). Summertime photochemical pollution in Beijing. Pure and Applied Chemistry, 67, 1465 - 1468 .

Tausz M, Grulke NE, Wieser G (2007). Defense and avoidance of ozone under global change. Environmental Pollution, 147, $525-531$

Tiedemann AV, Firsching KH (2000). Interactive effects of elevated ozone and carbon dioxide on growth and yield of leaf rust-infected versus non-infected wheat. Environmental Pollution, 108, $357-363$

Tingey DT, Laurence JA, Weber JA, Greene J, Hogsett WE, Brown S, Henry LE (2001). Elevated $\mathrm{CO}_{2}$ and temperature alter the response of Pinus ponderosa to ozone: a simulation analysis. Ecological Applications, 11, 1412 - 1424.

Tiwari S, Agrawal M, Manning WJ (2005). Assessing the impact of ambient ozone on growth and productivity of two cultivars of wheat in India using three rates of application of ethylenediurea (EDU) . Environmental Pollution, 138, 153-160.

Todd J (1958) . Responses of plants to air pollution. Plant Physiology, 27, $435-459$.

Torsethaugen G, Pell EJ, Assmann SM (1999). Ozone inhibits guard cell $\mathrm{K}^{+}$channels implicated in stomatal opening. Proceedings of the National Academy of Sciences of the United States of America, 96, 13577 - 13582.

Vingarzan R (2004) . A review of surface ozone background levels and trends. Atmospheric Environment, 38, 3431 - 3442 .
Volk M, Bungener P, Contat F, Montani M, Fuhrer J (2006). Grassland yield declined by a quarter in 5 years of free-air ozone fumigation. Global Change Biology, 12, 74-83.

Wang H, Kiang CS, Tang X, Zhou X, Chameides WL (2005). Surface ozone: a likely threat to crops in Yangtze delta of China. Atmospheric Environment, 39, 3843 - 3850 .

Wang SL (王淑兰), Chai FH (柴发合) (2002). Provincial characteristics of ozone pollution in Beijing. Scientia Geographica Sinica (地理科学), 22, $360-364$. (in Chinese with English abstract)

Wohlgemuth H, Mittelstrass K, Kschieschan S, Bender J, Weigel HJ, Overmyer K, Kangasjarvi J, Sandermann H, Langebartels C (2002). Activation of an oxidative burst is a general feature of sensitive plants exposed to the air pollutant ozone. Plant, Cell and Environment, 25, $717-726$.

Yamaji K, Julkunen-Tiitto R, Rousi M, Freiwald V, Oksanen E (2003) . Ozone exposure over two growing seasons alters root-toshoot ratio and chemical composition of birch (Betula pendula Roth. ). Global Change Biology, 9, 1363 - 1377.

Zhang YH (张远航), Shao KS (邵可声), Tang XY (唐孝炎), Li JL (李金龙) (1998). Study on photochemical smog pollution in cities of China. Acta Scientiarum Naturalium Universitatis Pekinensis (北京大学学报), 34, 392-400. (in Chinese with English abstract)

Zheng QW (郑启伟), Wang XK (王效科), Xie JQ (谢居清), Feng ZZ (冯兆忠), Feng ZW (冯宗炜), Ni XW (倪雄伟), Ouyang ZY (欧阳志云) (2006). Effects of exogenous ascorbate acid on membrane protective system of in situ rice leaves under $\mathrm{O}_{3}$ stress. Acta Ecologica Sinica (生态学报), 26, 1131 1137. (in Chinese with English abstract)

责任编委 : 段昌群 责任编辑 : 刘丽娟 